\title{
Bioactive Phenylpropanoids from Daphne feddei
}

\author{
Yanling Lu, ${ }^{a, b}$ Xuesen Li, ${ }^{a, b}$ Huaixue Mu, ${ }^{a}$ Haitao Huang, ${ }^{b}$ Gan-Peng $\mathrm{Li}^{*, a}$ and Qiufen Hu${ }^{*, a}$ \\ ${ }^{a}$ Key Laboratory of Ethnic Medicine Resource Chemistry (Yunnan University of Nationalities), \\ State Ethnic Affairs Commission \& Ministry of Education, Kunming 650031, P. R. China. \\ ${ }^{b}$ Key Laboratory of Tobacco Chemistry of Yunnan Province, Yunnan Academy of Tobacco Science, \\ Kunming 650106, P. R. China
}

\begin{abstract}
A investigação de extrato acetônico de folhas e caules de Daphne feddei forneceu três novos fenilpropanóides, fedeicetonas A-C (1-3), juntamente com nove fenilpropanóides conhecidos (4-11). Suas estruturas foram elucidadas com base em métodos espectroscópicos. Os compostos 1-3 foram testados com relação as suas atividades anti-HIV-1 e citotoxidades frente a células cancerígenas. Os resultados mostraram que as atividades citotóxicas e anti-HIV-1 dos compostos 1-3 são modestas.
\end{abstract}

\begin{abstract}
Investigation of acetone extract of the leaves and stems of Daphne feddei afforded three new phenylpropanoids, feddeiketones A-C (1-3), together with nine known phenylpropanoids (4-11). Their chemical structures were elucidated on the basis of spectroscopic methods. Compounds 1-3 were tested for their anti-HIV-1 activities and cytotoxicities against cancer cells. The results showed that compounds 1-3 have modest cytotoxic and anti-HIV-1 activities.
\end{abstract}

Keywords: Daphne feddei, phenylpropanoids, feddeiketones A-C, anti-HIV-1 activity, cytotoxic activity

\section{Introduction}

The genus Daphne (Thymelaeaceae) comprises about 70 species, 35 of which grow in China. Daphne feddei Levl., which is known as "Dian Rui Xiang" (Chinese), is distributed in Yunnan, Sichuan and Guizhou Provinces of China. It is a kind of evergreen shrub. Its leaves and stems have been used as folk medicine to treat the injuries from falls and bruises. ${ }^{1}$ Previous chemical studies on D. feddei Levl. led to the identification of diterpenes, monomeric coumarins, dicoumarins, flavonoids, biflavonoids, phenylpropanoids and lignans..$^{2-8}$ Among them, phenylpropanoids are important plant secondary metabolites with various biological activities, including antioxidant, anti-inflammatory, healing, antiviral and antimicrobial. ${ }^{9-11}$

Our previous studies on Daphne feddei collected from Dali Prefecture of Yunnan Province resulted in the isolation of several lignans and phenylpropanoids including two new secolignans and one new neolignan. ${ }^{12}$ As a continuation of investigation on chemical constituents of the same Daphne feddei plant, three new phenylpropanoids (1-3), together

*e-mail: ganpeng_li@sina.com, huqiufena@yahoo.com with nine known phenylpropanoids (4-12), were isolated. In addition, the anti-HIV-1 and cytotoxic activities of compounds 1-3 were evaluated. This article deals with the isolation, structural elucidation and biological activities of the new compounds.

\section{Results and Discussion}

The $70 \%$ aq. acetone extract of D. feddei was suspended in $\mathrm{H}_{2} \mathrm{O}$ and partitioned with ethyl acetate. The ethyl acetate partition was repeatedly subjected to column chromatography over Si gel and preparative HPLC (high performance liquid chromatography) to afford compounds 1-12, including three new phenylpropanoids, named feddeiketones A-C (1-3), together with nine known phenylpropanoids, $p$-coumaric acid (4), ${ }^{13}$ caffeic acid (5), ${ }^{14}$ ferulic acid (6), ${ }^{15}$ coniferoside (7), ${ }^{16}$ isoconiferin $(\mathbf{8}),{ }^{17}$ turbinataphenol A (9), ${ }^{18}$ nervolan B (10), ${ }^{19}$ nervolan $\mathrm{C}(\mathbf{1 1})^{20}$ and 1,2-O-dicaffeoylcyclopenta3-ol (12). ${ }^{21}$ The structures of compounds 1-12 are shown in Figure 1. In addition to three new compounds, compounds $\mathbf{8}, \mathbf{9}, \mathbf{1 0}, \mathbf{1 1}$ and 12 were isolated from the plant of Daphne genus for the first time. 
<smiles>[R7]OCCC(=O)c1cc([2H])c(O[R])c(O[R7])c1</smiles>

$1 R^{1}=R^{2}=-M e ; R^{3}=-H ; R^{4}=-A c$ $2 R^{1}=R^{2}=-M e ; R^{3}=R^{4}=-H$ $3 \mathrm{R}^{1}=-\mathrm{Me} ; \mathrm{R}^{2}=\mathrm{R}^{3}=-\mathrm{CH}_{2}-; \mathrm{R}^{4}=-\mathrm{H}$<smiles>[R]Oc1ccc(/C=C/C(=O)O)cc1[R]</smiles>

$4 \mathrm{R}^{1}=-\mathrm{H}, \mathrm{R}^{2}=-\mathrm{H}$ $5 \mathrm{R}^{1}=-\mathrm{H}, \mathrm{R}^{2}=-\mathrm{OH}$ $6 \mathrm{R}^{1}=-\mathrm{H}, \mathrm{R}^{2}=-\mathrm{OMe}$

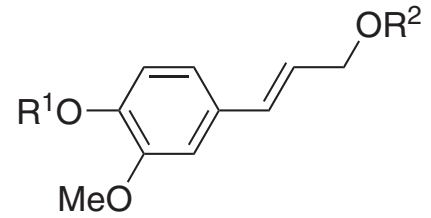

$7 \mathrm{R}^{1}=-\mathrm{Glc} ; \mathrm{R}^{2}=-\mathrm{H}$

$8 R^{1}=-H ; R^{2}=-G l c$<smiles>COC(=O)C1(O)C[C@H](O)[C@H](O)[C@H](OC(=O)/C=C/c2ccc(O)c(O)c2)C1</smiles>

9<smiles>[R]CCCc1cc([R1])c(OC)c(OC)c1</smiles>

$10 \mathrm{R}^{1}=-\mathrm{OMe} ; \mathrm{R}^{2}=-\mathrm{OH}$ $11 \mathrm{R}^{1}=-\mathrm{H} ; \mathrm{R}^{2}=-\mathrm{OH}$<smiles>Oc1ccc(/C=C/OC2CCC(O)C2O/C=C/c2ccc(O)c(O)c2)cc1O</smiles>

12

Figure 1. Chemical structures of compounds 1-12.

Compound 1 was isolated as pale yellow gum. Its molecular formula was established as $\mathrm{C}_{13} \mathrm{H}_{16} \mathrm{O}_{6}$ by a pseudo-molecular-ion peak in the HRESIMS (high-resolution electron spray ionization mass spectrometry) $\left(\mathrm{m} / \mathrm{z} 291.0852[\mathrm{M}+\mathrm{Na}]^{+}\right.$, calc. 291.0845). Its ${ }^{1} \mathrm{H}$ and ${ }^{13} \mathrm{C}$ NMR (nuclear magnetic resonance) spectra (Table 1) showed signals to 16 hydrogens and 13 carbons, respectively, corresponding to one aromatic ring $\left(\delta_{\mathrm{C}} 105.5,111.6,130.5,138.6,148.8,152.8\right)$ with two aromatic protons $\left(\delta_{\mathrm{H}} 6.82 d, J 1.8 \mathrm{~Hz} ; 7.06 d, J 1.8 \mathrm{~Hz}\right)$, one methylene group $\left(\delta_{\mathrm{C}} 42.0\right)$, one methylenedioxy group $\left(\delta_{\mathrm{C}} 60.0\right)$, one carbonyl group $\left(\delta_{\mathrm{C}} 198.0\right)$, two methoxyl groups $\left(\delta_{\mathrm{C}} 55.7,60.9\right)$, an acetoxy group $\left(\delta_{\mathrm{C}} 169.7\right.$, 21.3) and a phenolic hydroxyl group $\left(\delta_{\mathrm{H}} 10.98\right)$. Strong absorption bands accounting for hydroxyl $\left(3382 \mathrm{~cm}^{-1}\right)$, carbonyl $\left(1715,1705 \mathrm{~cm}^{-1}\right)$ and aromatic group (1636, $1508,1452 \mathrm{~cm}^{-1}$ ) could also be observed in its IR (infrared) spectrum. The UV spectrum of $\mathbf{1}$ showed absorption

Table 1. ${ }^{1} \mathrm{H}$ and ${ }^{13} \mathrm{C}$ NMR data (in $\mathrm{C}_{5} \mathrm{D}_{5} \mathrm{~N}$ ) of compounds $\mathbf{1 - 3}$

\begin{tabular}{|c|c|c|c|c|c|c|}
\hline \multirow{2}{*}{ Position } & \multicolumn{2}{|c|}{1} & \multicolumn{2}{|c|}{2} & \multicolumn{2}{|c|}{3} \\
\hline & $\delta_{\mathrm{C}}(\mathrm{m})$ & $\delta_{\mathrm{H}}(\mathrm{m}, J / \mathrm{Hz})$ & $\delta_{\mathrm{C}}(\mathrm{m})$ & $\delta_{\mathrm{H}}(\mathrm{m}, J / \mathrm{Hz})$ & $\delta_{\mathrm{C}}(\mathrm{m})$. & $\delta_{\mathrm{H}}(\mathrm{m}, J / \mathrm{Hz})$ \\
\hline 1 & $130.5(\mathrm{~s})$ & & $130.4(\mathrm{~s})$ & & $131.4(\mathrm{~s})$ & \\
\hline 2 & 111.6 (d) & $7.06(\mathrm{~d}, J 1.8)$ & 111.4 (d) & $7.05(\mathrm{~d}, J 1.9)$ & 111.1 (d) & $7.06(\mathrm{~d}, J 1.8)$ \\
\hline 3 & $148.8(\mathrm{~s})$ & & $149.0(\mathrm{~s})$ & & 143.7 (s) & \\
\hline 4 & $138.6(\mathrm{~s})$ & & $138.4(\mathrm{~s})$ & & 137.1 (s) & \\
\hline 5 & $152.8(\mathrm{~s})$ & & $152.7(\mathrm{~s})$ & & $148.5(\mathrm{~s})$ & \\
\hline 6 & 105.5 (d) & $6.82(\mathrm{~d}, J 1.8)$ & 106.0 (d) & $6.82(\mathrm{~d}, J 1.9)$ & 103.9 (d) & $7.32(\mathrm{~d}, J 1.8)$ \\
\hline 7 & $198.0(\mathrm{~s})$ & & $198.1(\mathrm{~s})$ & & $198.8(\mathrm{~s})$ & \\
\hline 8 & $42.0(\mathrm{t})$ & $3.43(\mathrm{t}, J$ 6.2) & $43.8(\mathrm{t})$ & $3.44(\mathrm{t}, J 6.2)$ & $43.7(\mathrm{t})$ & $3.32(\mathrm{t}, J 6.2)$ \\
\hline 9 & $60.0(\mathrm{t})$ & $4.66(\mathrm{t}, J$ 6.2) & $58.6(\mathrm{t})$ & $4.43(\mathrm{t}, J 6.2)$ & $58.9(\mathrm{t})$ & $4.44(\mathrm{t}, J 6.2)$ \\
\hline OMe-4 & $60.9(\mathrm{q})$ & $3.70(\mathrm{~s})$ & $60.7(\mathrm{q})$ & $3.70(\mathrm{~s})$ & & \\
\hline OMe-5 & $55.7(\mathrm{q})$ & $3.78(\mathrm{~s})$ & $55.7(\mathrm{q})$ & $3.74(\mathrm{~s})$ & $56.0(\mathrm{q})$ & $3.70(\mathrm{~s})$ \\
\hline$-\mathrm{OCH}_{2} \mathrm{O}-$ & & & & & $101.3(\mathrm{t})$ & $5.83,5.89(\mathrm{~s})$ \\
\hline $\mathrm{Ar}-\mathrm{OH}$ & & 10.98 (brs) & & 10.85 (brs) & & \\
\hline $1^{\prime}$ & $169.7(\mathrm{~s})$ & & & & & \\
\hline $2^{\prime}$ & $21.3(\mathrm{q})$ & $1.99(\mathrm{~s})$ & & & & \\
\hline
\end{tabular}


maxima at $289 \mathrm{~nm}$ confirming the existence of the aromatic function. The ${ }^{1} \mathrm{H}^{-}{ }^{1} \mathrm{H}$ COSY (correlation spectroscopy) of H-8/H-9, together with HMBC (heteronuclear multiple bond correlation) correlations (Figure 2) of aromatic protons, H-2 $\left(\delta_{\mathrm{H}} 7.06\right), \mathrm{H}-6\left(\delta_{\mathrm{H}} 6.82\right)$ with C-7 $\left(\delta_{\mathrm{C}} 198.0\right)$, of H-8 $\left(\delta_{\mathrm{H}} 3.43\right)$ with $\mathrm{C}-1\left(\delta_{\mathrm{C}} 130.5\right)$ and of $\mathrm{H}-9\left(\delta_{\mathrm{H}} 4.66\right)$ with $\mathrm{C}-1$ ' $\left(\delta_{\mathrm{C}} 169.7\right)$ suggested that $\mathbf{1}$ is a 3 -acetoxy1-phenyl-1-propanone ( $\mathrm{Ar}-\mathrm{CO}-\mathrm{CH}_{2}-\mathrm{CH}_{2} \mathrm{OAc}$ ) and possess two methoxyl groups and a phenolic hydroxyl group on the aromatic ring. The HMBC correlations of aromatic hydroxyl proton signal $\left(\delta_{\mathrm{H}} 10.98\right)$ with $\mathrm{C}-2\left(\delta_{\mathrm{C}} 111.6\right)$, C-3 $\left(\delta_{\mathrm{C}} 148.8\right), \mathrm{C}-4\left(\delta_{\mathrm{C}} 138.6\right)$ indicated that the hydroxyl group should be located at C-3. The HMBC correlations of two methoxyl proton signals $\left(\delta_{\mathrm{H}} 3.70,3.78\right)$ with $\mathrm{C}-4$ $\left(\delta_{\mathrm{C}} 138.6\right)$ and $\mathrm{C}-5\left(\delta_{\mathrm{C}} 152.8\right)$ indicated that two methoxyl groups should be located at C-4 and C-5, respectively. Therefore, the structure of $\mathbf{1}$ was elucidated as that shown in Figure 1, and it has been trivially named as feddeiketone A.

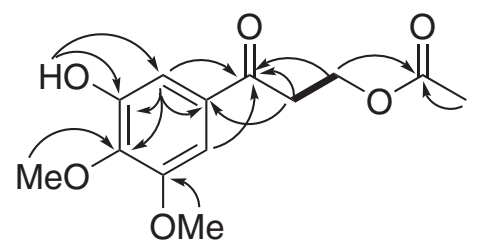

Figure 2. Selected $\mathrm{HMBC}(\frown)$ and ${ }^{1} \mathrm{H}-{ }^{1} \mathrm{H}$ COSY $(\leftrightharpoons)$ correlations of compound $\mathbf{1}$.

Compound 2, that was also obtained as pale yellow gum, has a molecular formula $\mathrm{C}_{11} \mathrm{H}_{14} \mathrm{O}$, based on the HRESIMS showing a sodiated molecular ion at $\mathrm{m} / \mathrm{z} 249.0731$ $[\mathrm{M}+\mathrm{Na}]^{+}$(calc. $m / z$ 249.0739). The ${ }^{1} \mathrm{H}$ and ${ }^{13} \mathrm{C}$ NMR spectra of $\mathbf{2}$ were very similar to those of $\mathbf{1}$. The IR and UV spectra were also similar to those of compound $\mathbf{1}$. The differences from 1 were the absence of the acetoxy group signal and the appearance of the hydroxyl proton signal $\left(\delta_{\mathrm{H}} 4.99 \mathrm{brs}\right)$ in $\mathbf{2}$. Therefore, the structure of $\mathbf{2}$ was established and was named feddeiketone B.

Compound $\mathbf{3}$ was also obtained as pale yellow gum. The ${ }^{1} \mathrm{H}$ and ${ }^{13} \mathrm{C}$ NMR spectra of $\mathbf{3}$ were very similar to those of 2 . The obvious chemical shift differences resulted from the substituent group variations in the aromatic ring. For compound 3 , the HMBC spectrum showed that a methoxyl group was located at C-3, and a methylenedioxy group at C-4 and C-5. Accordingly, the structure of $\mathbf{3}$ was determined as shown and named feddeiketone $\mathrm{C}$.

In the anti-HIV-1 tests, the cytotoxicity assay against C8166 cell $\mathrm{CC}_{50}$ (cause 50\% cells' death) was assessed using the MTT (1-(4,5-dimethylthiazol-2-yl)-3,5-diphenylformazan) method, and the anti-HIV-1 activity was evaluated by the inhibition assay for the cytopathic effects of HIV-1 $\left(\mathrm{EC}_{50}\right) \cdot{ }^{13}$ Compound $\mathbf{1}$ shows anti-HIV-1 activity with $\mathrm{EC}_{50}$
$3.96 \mu \mathrm{g} \mathrm{mL}-1, \mathrm{CC}_{50} 64.5 \mu \mathrm{g} \mathrm{ml}^{-1}$ and $\mathrm{TI}$ (therapeutic index) 16.3. Compound 2 shows anti-HIV-1 activity with $\mathrm{EC}_{50}$ $3.16 \mu \mathrm{g} \mathrm{mL}^{-1}, \mathrm{CC}_{50} 96.3 \mu \mathrm{g} \mathrm{ml}^{-1}$ and TI 30.5. Compound 3 shows anti-HIV-1 activity with $\mathrm{EC}_{50} 2.47 \mu \mathrm{g} \mathrm{mL}^{-1}, \mathrm{CC}_{50}$ $43.4 \mu \mathrm{g} \mathrm{mL}^{-1}$ and TI 17.6. The results showed that compounds 1-3 have modest anti-HIV-1 bioactivities.

The cytotoxicity tests for the isolates were performed using a previously reported procedure. ${ }^{22} \mathrm{All}$ treatments were performed in triplicate. In the MTT assay, the $\mathrm{IC}_{50}$ was defined as the concentration of the test compound resulting in a 50\% reduction of absorbance compared with untreated cells. The cytotoxic abilities of compound 1-3 against HL-60, Hep-G2, KB and MDA-MB-231 tumor cell lines were performed using the MTT-assay (with doxorubicin as the positive control). The results were shown in Table 2 and showed that compounds 1-3 have significant potential cytotoxic activities.

Table 2. Cytotoxicities of compounds 1-3

\begin{tabular}{lcccc}
\hline \multirow{2}{*}{ Compounds } & \multicolumn{4}{c}{ Cell lines } \\
\cline { 2 - 5 } & $\mathrm{HL}^{-60^{\mathrm{b}}}$ & HepG2 $^{\mathrm{c}}$ & $\mathrm{KB}^{\mathrm{d}}$ & MDA-MB-231 $^{\mathrm{e}}$ \\
\hline $\mathbf{1}$ & 3.27 & 1.55 & 1.35 & 2.47 \\
$\mathbf{2}$ & 2.08 & 1.18 & 2.84 & 10.5 \\
$\mathbf{3}$ & 1.96 & 4.62 & 1.28 & 3.67 \\
Doxorubicin $^{\mathrm{a}}$ & 0.1 & 0.2 & 0.1 & 0.1 \\
\hline
\end{tabular}

${ }^{a}$ Data of $\mathrm{IC}_{50}$ values in $\mu \mathrm{mol} \cdot \mathrm{L}^{-1}$. For a compound to be deemed effective, an $\mathrm{IC}_{50}$ value $<100 \mu \mathrm{mol} \cdot \mathrm{L}^{-1}$ is required. Doxorubicin was used as a

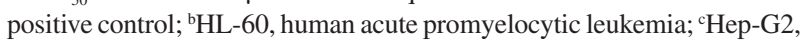
human hepatocellular carcinoma; ${ }^{\mathrm{d}} \mathrm{KB}$, human oropharyngeal epidermoid carcinoma; 'MDA-MB-231, human breast cancer cells.

\section{Conclusions}

The spectroscopic analyses of compounds isolated from leaves and stems of Daphne feddei. revealed three new phenylpropanoids (named feddeiketones A-C (1-3)), together with nine known phenylpropanoids (4-11). These new compounds had their cytotoxic activities and anti-HIV-1 bioactivity studied, with modest activities.

\section{Experimental}

\section{General procedures}

IR spectra were measured on a Bruker Tensor 27 spectrometer with $\mathrm{KBr}$ pellets. UV spectra were measured on a Shimadzu UV-2401A spectrophotometer. Optical rotations were measured on a Horiba SEPA-300 polarimeter. ${ }^{1} \mathrm{H}$ and ${ }^{13} \mathrm{C}$ NMR and 2D NMR spectra were recorded on Bruker DRX-500, with chemical shifts $(\delta)$ in ppm relative to tetramethylsilane (TMS) as internal standard and coupling constants in Hz. HRESIMS data were measured 
using an API QSTAR time-of-flight spectrometer and a VG Autospec-3000 spectrometer. Preparative HPLC was performed on a Shimadzu LC-8A preparative liquid chromatograph system equipped with a ZORBAX PrepHT $\mathrm{GF}(21.2 \mathrm{~mm} \times 25 \mathrm{~cm}, 7 \mu \mathrm{m})$ column or a Venusil $\mathrm{MPC}_{18}$ $(20 \mathrm{~mm} \times 25 \mathrm{~cm}, 5 \mu \mathrm{m})$ column. Silica gel (200-300 mesh, Qing-dao Marine Chemical, Inc., Qingdao, China) was used for column chromatography. Fractions were monitored by TLC (Qing-dao Marine Chemical, Inc., Qingdao, China), and spots were visualized by heating Si gel plates sprayed with $5 \% \mathrm{H}_{2} \mathrm{SO}_{4}$ in EtOH and under UV light.

\section{Plant material}

The leaves and stems of $D$. feddei were collected from Dali Prefecture, Yunnan Province, People's Republic of China, in September 2009, and authenticated by Professor Chen Y. J. (Yunnan University of Nationalities). A voucher specimen (YNNI 09-9-12) is deposited at the Herbarium of Key Laboratory of Ethnic Medicine Resource Chemistry, Yunnan University of Nationalities.

\section{Extraction and isolation}

Air-dried and powdered leaves and stems of D. fedde $i$ $(2.5 \mathrm{~kg})$ were extracted with $70 \%$ aqueous acetone $(4 \times 2.5 \mathrm{~L})$ at room temperature. After evaporating the solvents in vacuum, a residue was obtained (153 g). This residue was dissolved in $\mathrm{H}_{2} \mathrm{O}$ and extracted with EtOAc $(3 \times 1 \mathrm{~L})$. The EtOAc $(82.5 \mathrm{~g})$ extract was chromatographed on a silica gel (200-300 mesh) column and eluted with gradient mixtures of chloroform-acetone (20:1, 9:1, 8:2, $7: 3,6: 4,5: 5)$ to afford five fractions A-F. Fraction E (6:4, $38.4 \mathrm{~g}$ ) was subjected to silica gel column chromatography, eluted with chloroform-methanol (9:1, 8:2, 7:3, 6:4, 1:1), yielded subfractions E1-E5. Subfraction E1 (9:1, $2.47 \mathrm{~g}$ ) was further purified by preparative HPLC eluting with $\mathrm{H}_{2} \mathrm{O}-\mathrm{MeOH}\left(50: 50\right.$, flow rate $\left.12 \mathrm{ml} \mathrm{min}^{-1}\right)$ to give $\mathbf{1}$ $(21.2 \mathrm{mg}), \mathbf{3}(11.4 \mathrm{mg}), \mathbf{9}(22.6 \mathrm{mg})$ and $\mathbf{1 0}(8.62 \mathrm{mg})$. Subfraction E2 $(8: 2,3.68 \mathrm{~g})$ was subjected to preparative HPLC eluting with $\mathrm{H}_{2} \mathrm{O}-\mathrm{MeOH}(58: 42$, flow rate $\left.12 \mathrm{~mL} \mathrm{~min}^{-1}\right)$ to afford $\mathbf{2}(18.5 \mathrm{mg}), \mathbf{1 1}(35.4 \mathrm{mg})$ and $\mathbf{1 2}$ (4.58 mg). Subfraction E3 (3:2, $9.2 \mathrm{~g})$ was also further purified by preparative HPLC eluting with $\mathrm{H}_{2} \mathrm{O}-\mathrm{MeOH}$ (80:20, flow rate $\left.12 \mathrm{~mL} \mathrm{~min}^{-1}\right)$ to afford $4(50.5 \mathrm{mg})$, $5(36.5 \mathrm{mg}), \mathbf{6}(24.6 \mathrm{mg}), \mathbf{7}(63.5 \mathrm{mg})$ and $\mathbf{8}(41.2 \mathrm{mg})$.

\section{Anti-HIV-1 assay}

Cytophatic effect inhibitory assay using C8166 cells infected with HIV-1 was used to evaluate anti-HIV-1 activity $\left(\mathrm{EC}_{50}\right)$. The cytotoxicities of compounds 1-3 against $\mathrm{C} 8166$ cells $\left(\mathrm{CC}_{50}\right)$ were also evaluated using the MTT method and allowed the determination of therapeutic index (TI). ${ }^{21}$

\section{Cytotoxicity assay}

Cytotoxic activities of compounds 1-3 against cancer cell lines HL-60, Hep-G2, KB and MDA-MB-231 were measured by the MTT method using doxorubicin as the positive control. ${ }^{22}$

\section{Feddeiketone A (1)}

Pale yellow gum; UV (MeOH) $\lambda_{\max } / \mathrm{nm}(\log \varepsilon) 324$ $\left(\delta_{\mathrm{H}} 2.47\right), 289\left(\delta_{\mathrm{H}} 4.18\right), 250\left(\delta_{\mathrm{H}} 3.26\right), 210\left(\delta_{\mathrm{H}} 4.82\right)$; IR (KBr) $v_{\text {max }} / \mathrm{cm}^{-1} 3382,2923,2852,1715,1705,1636$, 1508, 1452, 1432, 1360, 1280, 1172, 1138, 1089, 1043, 976, 825; ${ }^{1} \mathrm{H} \mathrm{NMR}\left(\mathrm{C}_{5} \mathrm{D}_{5} \mathrm{~N}, 500 \mathrm{MHz}\right)$ and ${ }^{13} \mathrm{C}$ NMR data $\left(\mathrm{C}_{5} \mathrm{D}_{5} \mathrm{~N}, 125 \mathrm{MHz}\right)$ see Table 1; positive-mode ESIMS $\mathrm{m} / \mathrm{z} 291[\mathrm{M}+\mathrm{Na}]^{+}$; HRESIMS $\mathrm{m} / \mathrm{z}, 291.0852[\mathrm{M}+\mathrm{Na}]^{+}$ (calc. for $\mathrm{C}_{13} \mathrm{H}_{16} \mathrm{NaO}_{6}, 291.0845$ ).

\section{Feddeiketone B (2)}

Pale yellow gum; UV (MeOH) $\lambda_{\max } / \mathrm{nm}(\log \varepsilon) 325$ $\left(\delta_{\mathrm{H}} 2.44\right), 288\left(\delta_{\mathrm{H}} 4.16\right), 250\left(\delta_{\mathrm{H}} 3.18\right), 210\left(\delta_{\mathrm{H}} 4.89\right)$; IR (KBr) $v_{\max } / \mathrm{cm}^{-1} 3408,2924,2857,1718,1632,1516$, 1458, 1362, 1276, 1160, 1085, 974, 820; ${ }^{1} \mathrm{H}$ NMR $\left(\mathrm{C}_{5} \mathrm{D}_{5} \mathrm{~N}, 500 \mathrm{MHz}\right)$ and ${ }^{13} \mathrm{C} \mathrm{NMR}$ data $\left(\mathrm{C}_{5} \mathrm{D}_{5} \mathrm{~N}, 125 \mathrm{MHz}\right)$ see Table 1; positive-mode ESIMS $m / z 249[\mathrm{M}+\mathrm{Na}]^{+}$; HRESIMS $m / 2,249.0731[\mathrm{M}+\mathrm{Na}]^{+}$(calc. for $\mathrm{C}_{11} \mathrm{H}_{14} \mathrm{NaO}_{5}$, 249.0739).

\section{Feddeiketone C (3)}

Pale yellow gum; UV (MeOH), $\lambda_{\max } / \mathrm{nm}(\log \varepsilon), 325$ $\left(\delta_{\mathrm{H}} 2.57\right), 287\left(\delta_{\mathrm{H}} 4.22\right), 250\left(\delta_{\mathrm{H}} 3.26\right), 210\left(\delta_{\mathrm{H}} 4.82\right)$; IR (KBr) $v_{\text {max }} / \mathrm{cm}^{-1} 3412,2925,2862,1718,1628,1518$, 1462, 1453, 1273, 1156, 1082, 951, 862; ${ }^{1} \mathrm{H}$ NMR $\left(\mathrm{C}_{5} \mathrm{D}_{5} \mathrm{~N}, 500 \mathrm{MHz}\right)$ and ${ }^{13} \mathrm{C}$ NMR data $\left(\mathrm{C}_{5} \mathrm{D}_{5} \mathrm{~N}, 125 \mathrm{MHz}\right)$ see Table 1; positive-mode ESIMS $m / z 247[\mathrm{M}+\mathrm{Na}]^{+}$; HRESIMS $m / z 247.0587[\mathrm{M}+\mathrm{Na}]^{+}$(calc. for $\mathrm{C}_{11} \mathrm{H}_{12} \mathrm{NaO}_{5}$, 247.0582).

\section{Supplementary Information}

${ }^{13} \mathrm{C}$ NMR, DEPT and ${ }^{1} \mathrm{H}$ NMR spectra of feddeiketones A-C, HSQC, HMBC, HRESIMS spectra of feddeiketone A, are available free of charge at http://jbcs.sbq.org.br as PDF file. 


\section{Acknowledgments}

We wish to acknowledge financial support from the Excellent Scientific and Technological Team of Yunnan High School (2010CI08), the Young Academic and Technical Leader Rising Foundation of Yunnan Province \& Yunnan University of Nationalities (2007PY01-27) and Open Research Fund Program of Key Laboratory of Ethnic Medicine Resource Chemistry, State Ethnic Affairs Commission \& Ministry of Education, School of Chemistry and Biotechnology, Yunnan University of Nationalities (2010XY08).

\section{References}

1. Putian, L.; Jiang, Y.; Flora of China; Chinese Science Press: Beijing, 1977.

2. Liang, S.; Feng, Y.; Tian, J. M.; Lu, M.; Xiong, Z.; Zhang, W. D.; J. Asian Nat. Prod. Res. 2011, 13, 1074.

3. Li, S. H.; Wu, L. J.; Gao, Y. H.; J. Asian Nat. Prod. Res. 2005, 7,838 .

4. Liang, S.; Tang, J.; Shen, Y. H.; Jin, H. Z.; Tian, J. M.; Wu, Z. J.; Zhang, W. D.; Yan, S. K.; Chem. Pharm. Bull. 2008, 56, 1729.

5. Liu, X.; Ye, W. C.; Che, Z.T.; Zhao, S. X.; J. China Pharm. Univ. 2003, 34, 116.

6. Liang, S.; Shen, Y. H.; Tian, J. M.; Wu, Z. J.; Jin, H. Z.; Zhang, W. D.; Yan, S. K.; J. Nat. Prod. 2008, 71, 1902.

7. Hu, X. J.; Jin, H. Z.; Su, J.; Zhang, W. X.; Wen, Z.; Yan, S. K.; Liu, R. H.; Li, J. Q.; Zhang, W. D.; Chin. J. Nat. Med. 2009, 7, 34.

8. Liao, S. G.; Zhang, B. L.; Wu, Y.; Helv. Chim. Acta 2005, 88, 2873.
9. Kim, W.; Seong, K. M.; Youn, B.; Exp. Mol. Med. 2011, 43, 323.

10. Kazufumi, Y.; Kanako, S.; Yusuke T.; Phytochemistry 2009, 70, 1739.

11. Gálvez, M.; Martín-Cordero, C.; Ayuso, M. J.; Stud. Nat. Prod. Chem. 2006, 33, 675.

12. Hu, Q. F.; Mu, H. X.; Huang, H. T.; Lv, H. Y.; Li, S. L.; Tu, P. F.; Li, G. P.; Chem. Pharm. Bull. 2011, 59, 1421.

13. Harris, P. J.; Hartley, R. D.; Biochem. Syst. Ecol. 1980, 8, 153.

14. Morozova, E. V.; Korableva, N. P.; Sukhova, L. S.; Chem. Nat. Compd. 1975, 11, 92.

15. Kosmolak, F. G.; Rohringer, R.; Prep. Biochem. Biotechnol. 1974, 4, 499

16. Tolonen, A.; Pakonen, M.; Hohtola, A.; Jalonen, J.; Chem. Pharm. Bull. 2003, 51, 467.

17. Nakanishi, T.; I ida, N.; Inatomi, Y.; Murata, H.; Inada, A.; Murata, J.; Lang, F. A.; Iinuma, M.; Tanaka, T.; Heterocycles 2004, 63, 2573.

18. Cardoso, C. L.; Hiroshiro, H.; Silva, D. H. S.; Bolzani, V. S.; Berova, N.; Nakanishi, K.; J. Nat. Prod. 2006, 69, 1046.

19. Yan, L.; Huang, Y.; Fu, J. J.; Qin, J. J.; Zeng, Q.; Zhu, Y.; Yan, S. K.; Zhang, W. D.; Jin, H. Z.; Helv. Chim. Acta 2010, 93, 265.

20. Nhiem, N. X.; Kimc, K. C.; Kimd, A. D.; Hyunc, J. W.; J. Asian Nat. Prod. Res. 2011, 13, 56.

21. Wang, J. H.; Tam, S. C.; Huang, H.; Yang, D. Y.; Wang, Y. Y.; Zheng, Y. T.; Biochem. Biophys. Res. Commun. 2004, 317, 965.

22. Mosmann, T.; J. Immunol. Methods 1983, 65, 55.

Submitted: August 17, 2011 Published online: February 16, 2012 